\title{
Correction to: Excited delirium syndrome from psychostimulant abuse can mimic a violent scene of death
}

\author{
Shatishraj Jothee, Mohamed Swarhib Shafie and Faridah Mohd Nor ${ }^{*}$
}

\section{Correction to: Egypt J Forensic Sci (2019) 9:64 \\ https://doi.org/10.1186/s41935-019-0173-z}

After the publication of this article (Jothee et al. 2019) it was brought to the authors' attention that the appropriate consent statement was not included in the manuscript. The correct statement is given below:

Written informed consent was obtained from the patient's next of kin for publication of this case report and any accompanying images. A copy of the written consent is available for review by the Editor-in-Chief.

Published online: 15 July 2020

\section{Reference}

Jothee S, Shafie MS, Nor FM (2019) Excited delirium syndrome from

psychostimulant abuse can mimic a violent scene of death. Egypt J Forensic

Sci 9:64. https://doi.org/10.1186/s41935-019-0173-z

*Correspondence: mnfaridah@gmail.com

The original article can be found online at https://doi.org/10.1186/s41935019-0173-z

Forensic Unit, Department of Pathology, Medical Faculty UKM, Hospital Canselor Tuanku Muhriz, Jalan Yaacob Latiff, Bandar Tun Razak, Cheras, 56 000, Kuala Lumpur, Malaysia

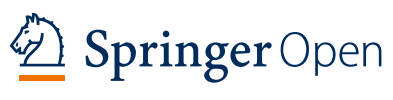

( ) The Author(s). 2020 Open Access This article is licensed under a Creative Commons Attribution 4.0 International License, which permits use, sharing, adaptation, distribution and reproduction in any medium or format, as long as you give appropriate credit to the original author(s) and the source, provide a link to the Creative Commons licence, and indicate if changes were made. The images or other third party material in this article are included in the article's Creative Commons licence, unless indicated otherwise in a credit line to the material. If material is not included in the article's Creative Commons licence and your intended use is not permitted by statutory regulation or exceeds the permitted use, you will need to obtain permission directly from the copyright holder. To view a copy of this licence, visit http://creativecommons.org/licenses/by/4.0/. 